\title{
Purification of pectinase from mango (Mangifera indica L. cv. Chokanan) waste using an aqueous organic phase system: a potential low cost source of the enzyme
}

\begin{abstract}
As a novel method of purification, an aqueous organic phase system (AOPS) was employed to purify pectinase from mango waste. The effect of different parameters, such as the alcohol concentration (ethanol, 1-propanol, and 2-propanol), the salt type and concentration (ammonium sulfate, potassium phosphate and sodium citrate), the feed stock crude load, the aqueous phase $\mathrm{pH}$ and $\mathrm{NaCl}$ concentration, were investigated in the recovery of pectinase from mango peel. The partition coefficient $(\mathrm{K})$, selectivity $(\mathrm{S})$, purification factor $(\mathrm{PF})$ and yield $(\mathrm{Y}, \%)$ were investigated in this study as important parameters for the evaluation of enzyme recovery. The desirable partition efficiency for pectinase purification was achieved in an AOPS of $19 \%(\mathrm{w} / \mathrm{w})$ ethanol and $22 \%(\mathrm{w} / \mathrm{w})$ potassium phosphate in the presence of $5 \%$ $(\mathrm{w} / \mathrm{w}) \mathrm{NaCl}$ at $\mathrm{pH}$ 7.0. Based on the system, the purification factor of pectinase was enhanced 11.7 , with a high yield of $97.1 \%$.
\end{abstract}

Keyword: Purification; Organic solvent; Aqueous organic phase system; Pectinase; Mango peel 